\title{
KONSERVATISME AKUNTANSI DAN KEPERCAYAAN INVESTOR
}

\author{
F. Tanti Anita ${ }^{a}$ \\ Zaenal Fanani ${ }^{\mathbf{b}}$ \\ ${ }^{a}$ Sekolah Pascasarjana Universitas Airlangga ${ }^{b}$ Fakultas Ekonomi dan Bisnis Universitas Airlangga \\ Email: anitaftanti@gmail.com ${ }^{\mathrm{a}}$; fanani@feb.unair.ac.id ${ }^{\mathrm{b}}$
}

ARTICLE HISTORY

Received:

21 June 2017

Revised

22 July 2017

Accepted:

9 August 2017

Online available:

9 November 2017

Keywords :

Accounting conservatism and Investor trust

\section{ABSTRACT}

This research intended to test the influence of accounting conservatism explanations such as contracting, litigation, taxation, and regulation to investor trust. In this case, the indicator of the investor trust can be seen from the stock return. A number of manufacturing companies registered in Indonesia stock exchange from year 2008 to 2012 was used as samples in this research. The test of the influence of accounting conservatism explanations to stock return has been done by using double regression analysis. Based on the result of the test, the accounting conservatism explanations for contracting, litigation and regulation has no significant influence to stock return. On the contrary, it has positively significant influence to taxation.

\section{LATAR BELAKANG}

Pasar modal mempunyai peranan penting bagi dunia perekonomian dewasa ini. Pasar modal mempunyai dua fungsi penting yaitu : fungsi keuangan dan fungsi ekonomi. Fungsi ekonomi pasar modal memberikan fasilitas yang mempertemukan dua kepentingan yaitu pihak yang memerlukan (investor) dan pihak yang membutuhkan (issuer). Sedangkan fungsi keuangan pasar modal memberikan kemungkinan dan kesempatan untuk memperoleh imbalan (return) bagi mereka yang memiliki dana. Para pemilik dana memperoleh informasi tentang perusahaan melalui laporan keuangan yang dibuat oleh manajemen. Laporan keuangan dibuat oleh manajemen untuk menggambarkan kinerja manajemen dalam mengelola sumber daya perusahaan. Salah satu indikator bahwa suatu informasi akuntansi relevan adalah adanya reaksi dari adanya reaksi pemodal pada saat diumumkan suatu informasi yang dapat diamati dari adanya pergerakan return dan saham. Pelaporan keuangan adalah informasi mengenai 
laba dan komponennya dimana laba merupakan parameter kinerja perusahaan yang mendapat perhatian utama dari investor dan kreditur. Prinsip akuntansi yang berlaku umum (Generally Accepted Accounting Principles) memberikan fleksibilitas bagi manajemen dalam menentukan metode maupun estimasi akuntansi yang dapat digunakan. Fleksibilitas tersebut akan mempengaruhi perilaku manajer dalam melakukan pencatatan akuntansi dan pelaporan transaksi keuangan perusahaan. Dalam kondisi keragu-raguan seorang manajer harus menerapkan prinsip akuntansi yang bersifat konservatis. Prinsip konservatisme merupakan prinsip kehati-hatian terhadap suatu keadaan yang tidak pasti untuk menghindari optimisme berlebihan dari manajemen dan pemilik perusahaan. Konservatisme merupakan prinsip akuntansi yang jika diterapkan akan menghasilkan angka-angka pendapatan dan asset yang cenderung rendah, serta angka-angka biaya yang cenderung tinggi. Kecenderungan seperti itu terjadi karena konservatisme menganut prinsip memperlambat pengakuan pendapatan serta mempercepat pengakuan biaya. Alasan penurunan ini didasarkan pada pandangan bahwa laba bersih tidak mencerminkan perubahan ekonomi riil. (Watts, 2003b) menawarkan empat penjelasan untuk penggunaan praktik konservatisme akuntansi yaitu : contracting, litigasi, regulasi dan perpajakan. Akibatnya, tujuan pelaporan konservatisme adalah untuk untuk meningkatkan efisiensi kontrak, mengatasi litigasi pemegang saham terhadap perusahaan dan auditor, untuk meningkatkan kualitas laporan keuangan perusahaan dengan adanya intervensi dari peraturan pemerintah, dan untuk mengurangi penundaan kewajiban pajak. Dalam penelitian (Qiang, 2007) lebih lanjut meneliti masing-masing faktor dan berpendapat bahwa concracting menghasilkan konservatisme bersyarat, litigasi menghasilkan konservatisme bersyarat dan tidak bersyarat, sedangkan regulasi dan perpajakan menghasilkan konservatisme bersyarat. Secara keseluruhan temuan ini menunjukkan bahwa ada peran yang berbeda untuk masing-masing penjelasan konservatisme akuntansi.

\section{TINJAUAN PUSTAKA}

Teori Keagenan (agency theory) yang dikemukakan oleh (Jensem \& Meckling, 1976) menyatakan bahwa kepentingan manajemen dan kepentingan pemegang saham seringkali bertentangan, sehingga bisa menyebabkan konflik diantara keduanya. Hal ini lebih disebabkan antara lain karena manajer cenderung berusaha mengutamakan kepentingan pribadi daripada pada kepentingan pemegang saham. Teori keagenan yang dikemukakan oleh (Jensen dan Meckling, 1976) menyatakan bahwa yang disebut principal adalah pemegang saham dan yang dimaksud dengan agent adalah para professional/manajemen/CEO, yang dipercaya oleh principal untuk mengelola perusahaan. 


\section{Definisi Konservatisme Akuntansi}

Dalam penyajian laporan keuangan, akuntan dapat memilih metode akuntansi apa yang akan diterapkan. Dalam konservatisme, akuntan dihadapkan dalam pilihan dua atau lebih teknik akuntansi. Konservatisme merupakan prinsip yang paling mempengaruhi penilaian dalam akuntansi. Akuntan dapat memilih metode yang berdampak lebih rendah pada laba dalam menyajikan laporan keuangan yang konservatif. Secara tradisional, konservatisme didefinisikan sebagai antisipasi terhadap semua rugi tetapi tidak mengantisipasi laba (Watts, 2003a). Menurut The Financial Standard Board (FASB) Concept Statement No.2, konservatisme akuntansi didefinisikan sebagai sikap kehati-hatian (prudence) terhadap ketidakpastian dalam pengakuan suatu kejadian ekonomi (FASB, 1983).

\section{Penelitian Sebelumnya}

Dibawah ini kami menjelaskan beberapa penelitian empiris yang membahas secara komprehensif tentang konservatisme akuntansi dan beberapa penjelasan konservatsime akutansi yaitu : contracting, litigasi, regulasi dan perpajakan. Penelitian sebelumnya (Watts, 2003a, 2003b), (Leone et al., 2006) dan (Qiang, 2007) memberikan penjelasan konservatisme akuntansi dari perspektif permintaan pengguna laporan keuangan. (Watts, 2003a, 2003b) mengklasifikasikan penjelasan konservatisme menjadi empat yaitu : contracting, litigasi, regulasi dan perpajakan. (Qiang, 2007) lebih lanjut menguraikan penjelasan konservatisme apakah mereka termasuk konservatisme bersyarat atau konservatisme tanpa syarat dan menyediakan masing-masing proxy untuk masing-masing penjelasan dari konservatisme akuntansi. Empat penjelasan akuntansi dalam konservatisme akuntansi dan menentukan relevansi nilai sangat penting untuk banyak alasan. Secara umum, temuan yang mendukung adanya peningkatan relevansi nilai dari nilai laba didukung oleh penelitian (Ball et al., 2008) yang menyatakan bahwa pasar ekuitas bukanlah satu-satunya bagian yang membutuhkan informasi keuangan, sehingga mendukung penelitian yang menemukan hubungan yang signifikan atau perubahan $\mathrm{R}^{2}$ dari waktu ke waktu menggunakan konservatisme akuntansi sebagai proxy yang merupakan figure penting dari pelaporan keuangan, mereka menemukan bahwa (Balachandran \& Mohanram, 2011) pasar utang sebagai lawan pasar modal yang positif dan signifikan terkait dengan konservatisme. Jika informasi yang diminta oleh pasar utang lebih banyak, ini biasa menjelaskan mengapa tidak ada bukti yang mendukung secara langsung relevansi nilai konservatisme akuntansi dari waktu ke waktu di pasar ekuitas. (Watts, 2003b) menyatakan bahwa konservatisme merupakan mekanisme untuk melakukan efisiensi kontrak, dimana manajer berkomitmen untuk melaporkan secara 
konservatisme untuk mengurangi biaya keagenan. (Watts, 2003b) juga menyatakan bahwa salah satu penjelasan conctracing untuk konservatisme akuntansi diskresionaer didasarkan pada teori keagenan. Menurut teori keagenan, manajer (agents) terikat dengan tindakan oportunistik untuk memaksimalkan kesejahteraannya sendiri dengan mengorbankan kepentingan pemegang saham, debt holders, dan pihak concracting lainnya. Selain itu penjelasan risiko litigasi terhadap konservatisme menyatakan bahwa risiko litigasi menurut undang-undang pasar modal mendorong konservatisme. Risiko litigasi cenderung dipengaruhi oleh pernyatan yang berlebihan dibandingkan pernyataan yang lebih rendah dari laba dan asset bersih, oleh karena itu manajemen dan auditor mempunyai inisiatif untuk menyatakan lebih rendah laba dan asset bersih (Watts, 2003b) dan (Basu, 1997). Sedangkan dalam penelitian (Beaver, 2002) menyatakan bahwa terdapat 5 (lima) area utama dalam pasar modal yaitu efisiensi pasar, model FelthamOhlson, nilai relevan, perilaku analisis, dan perilaku diskresi (discretionary). Masingmasing penelitian tersebut mengundang kontroversi baik yang berkaitan dengan penelitian maupun dari metodologi yang digunakan dalam penelitian tersebut. (Ohlson, 1995) dalam penelitiannya menunjukkan bahwa model yang menjelaskan bagaimana nilai pasar perusahaan berkaitan dengan data akuntansi yang mengungkapkan hasil dari kedua aktivitas, yaitu aktivitas operasi dan aktivitas keuangan. Masing-masing dari dua aktivitas atau kegiatan tersebut mengangkat masalah pengukuran akuntansi yang berbeda, yang mempengaruhi analisis dari nilai pasar perusahaan sebagai fungsi dari komponen laporan keuangan. Kegiatan keuangan melibatkan asset dan kewajiban yang ada dimana pasar adalah relatif sempurna. Oleh karena itu, diharapkan perusahaan dapat menemukan konsep pengukuran akuntansi yang masuk akal sehingga nilai buku dan nilai pasar bertepatan dengan aktiva dan kewajiban. (Lev \& Sougiannis, 1996) meneliti tentang hubungan antara waktu perusahaan mengkapitalisasi biaya $R$ \& $D$ dengan return saham dengan menggunakan variabel dependent return dan harga saham dan variabel independentnya earnings per share, earnings dengan biaya R \& D dan earnings sebelum biaya R \& D. Penelitian ini menghasilkan hubungan yang signifikan antara waktu perusahaan mengkapitalisasi biaya $\mathrm{R} \& \mathrm{D}$ dengan return dan harga saham. (Lo, 2005) hasil penelitiannya menunjukan bahwa semua koefisien variabel tingkat kesulitan keuangan perusahaan bertanda positif signifikan. Hasil tersebut mendukung hipotesis teori signaling teori bahwa tingkat kesulitan keuangan perusahaan berpengaruh positif terhadap tingkat konservatisme akuntansi. Hasil tersebut tidak mendukung hipotesis teori akuntansi positif bahwa tingkat kesulitan keuangan perusahaan berpengaruh negatif terhadap tingkat konservatisme akuntansi. Peneliti juga mendefinisikan konservatisme sebagai suatu pandangan pesimistik dalam akuntansi. (Beatty et al., 2008) dalam penelitiannya menyatakan bahwa escalator pendapatan 
cenderung digunakan ketika ada peningkatan agency cost. Sedangkan penerapan konservatisme dan adanya modifikasi kontrak diperlukan untuk memenuhi tuntutan pemberi pinjaman. (Ahmed et al., 2002) menyatakan bahwa perusahaan dengan konflik kebijakan dividen bondholder-shareholder, rata-rata menggunakan akuntansi konservatisme, perusahaan yang mengadopsi praktek akuntansi konservatisme menjadikan biaya hutang lebih rendah. Hal ini juga dipengaruhi oleh variabel control yaitu profitabilitas, ukuran perusahaan dan pertumbuhan perusahaan. Penelitian (Penman \& Zhang, 2002) berpendapat bahwa konservatisme dianggap kurang relevan dalam mengambil keputusan karena konservatisme menghasilkan kualitas laba yang rendah. Selain itu mereka beranggapan bahwa konservatisme akuntansi tidak hanya berkaitan dengan pemilihan metode akuntansi tetapi juga estimasi yang sering diterapkan berkaitan dengan akuntansi akrual. Dalam penelitian (Ahmad, 2007) menemukan bahwa konflik kepentingan berpengaruh positif terhadap hal ini mendukung penelitian (Ahmed et al., 2002) semakin tinggi intensitas konflik kepentingan, maka semakin tinggi kecenderungan penerapan konservatisme akuntansi. Risiko litigasi terhadap hubungan konflik kepentingan dan konservatisme akuntansi bersifat melemahkan, hal ini menunjukkan bahwa semakin tinggi risiko litigasi perusahaan, maka hubungan positif konflik kepentingan dan konservatisme akuntansi semakin lemah. Strategi perusahaan terhadap hubungan antara konflik kepentingan dan konservatisme akuntansi bersifat memperlemah. Hal ini menunjukkan bahwa ketika perusahaan bertipe pros-pektor maka hubungan positif konflik kepentingan dan konservatisme semakin lemah. Demikian sebaliknya, ketika perusahaan bertipe defender, maka hubungan positif kepentingan dan konservatisme akuntansi.

\section{METODE PENELITIAN}

\section{Pemilihan Sampel dan Pengumpulan Data}

Penelitian ini mengkaji tentang konservatisme akuntansi terhadap kepercayaan investor. Berdasarkan karakteristik masalah yang diteliti, penelitian ini dapat diklasifikasikan ke dalam penelitian kausal komparatif. Populasi dalam penelitian ini adalah semua perusahaan manufaktur yang terdaftar di Bursa Efek Indonesia (BEI).

\section{Variabel Penelitian dan Pengukurannya}

Variabel yang digunakan dalam penelitian ini terdiri atas variabel-variabel yang berkaitan dengan konservatisme akuntansi. Variabel-variabel yang berkaitan dengan return saham adalah penjelasan dari konservatisme akuntansi yang terdiri dari concracting, litigasi, regulasi, perpajakan.

\section{Teknis Analisis Data dan Uji Hipotesis}


Analisis data dan pengujian hipotesis yang dilakukan dengan menggunakan program komputer yaitu SPSS (Statistical Product and Service Solution) for windows dan Mikrosoft Excel 2010.

\section{Analisis Regresi Berganda}

Analisi ini digunakan untuk mengetahui ada atau tidaknya pengaruh concracting, litigati, regulasi dan perpajakan sebagai variabel bebas (independent variabel) terhadap kepercayaan investor dalam hal ini return saham sebagai variabel terikat (dependent variabel).

Pembuktian hipotesis pada penelitian ini menggunakan model regresi berganda dengan 4 variabel bebas adalah sebagai berikut :

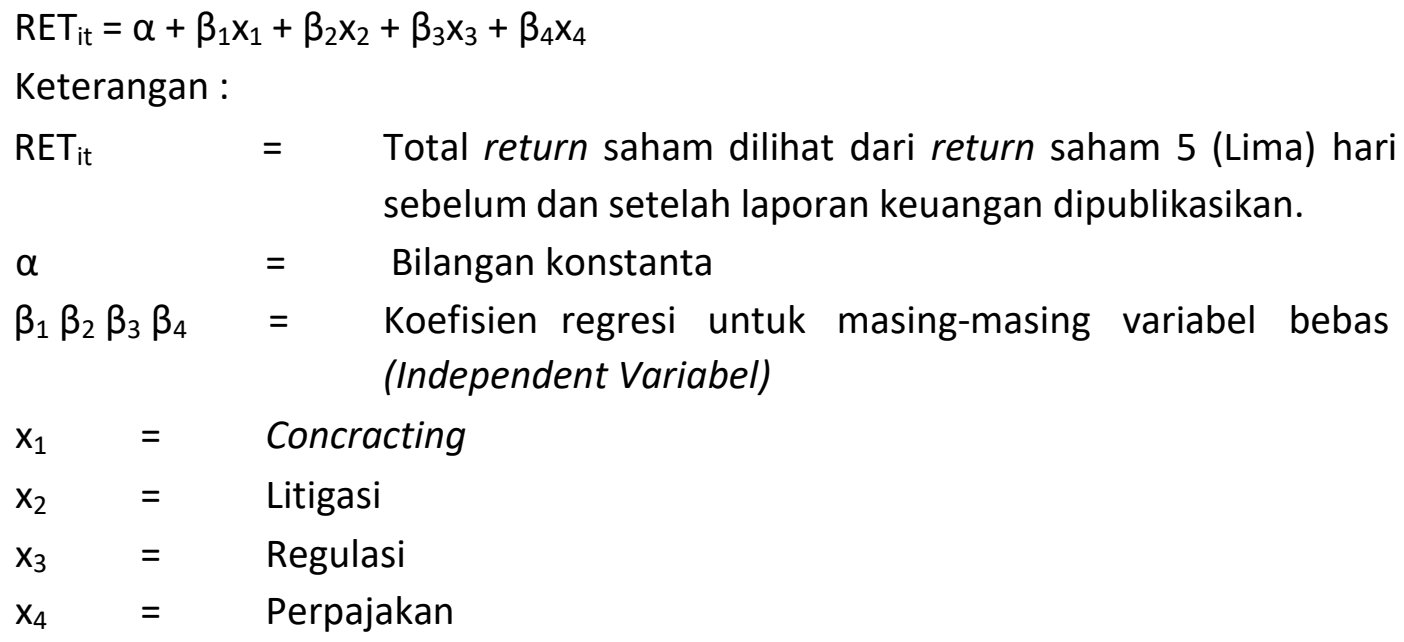

Tahap selanjutnya untuk Analisis untuk regresi adalah sebagi berikut :

\section{Pengujian Hipotesis}

\section{Uji Koefisien Determinasi $\left(\mathbf{R}^{2}\right)$}

Koefisien determinasi $\left(R^{2}\right)$ berguna untuk mengukur seberapa jauh kemampuan model dalam menerangkan variasi variabel dependent. Nilai koefisien determinasi adalah antara nol dan satu. Nilai $\mathrm{R}^{2}$ yang kecil berarti kemampuan variabel-variabel independent dalam menjelaskan variasi variabel-variabel dependent sangat terbatas. Nilai yang mendekati satu berarti variabel-variabel independent memberikan hampir semua informasi yang dibutuhkan untuk memprediksi variabel dependent. Nilai $\mathrm{R}^{2}$ digunakan untuk mengukur tingkat kemampuan model dalam menerangkan variabel dependent. Tetapi karena $\mathrm{R}^{2}$ mengandung kelemahan mendasar, yaitu adanya bias terhadap jumlah variabel independent yang dimasukkan dalam model, maka penelitian 
ini menggunakan adjusted $\mathrm{R}^{2}$ berkisar antara nol dan satu. Jika nilai adjusted $\mathrm{R}^{2}$ semakin mendekati satu maka makin baik kemampuan model tersebut dalam menjelaskan variabel dependent.

\section{Uji parsial (T test)}

Pengujian ini bertujuan untuk menunjukkan seberapa jauh pengaruh satu variabel penjelas/independent secara individual dalam menerangkan variasi variabel dependent. Pengujian dilakukan dengan menggunakan significance level 0,05 ( $\alpha=5 \%$ ).

\section{HASIL PENELITIAN DAN ANALISA}

Penelitian ini membahas tentang konservatisme akuntansi dan kepercayaan investor. Konservatisme akuntansi dilihat dari beberapa penjelasan yaitu concracting, litigasi, perpajakan dan regulasi. Sedangkan kepercayaan investor dilihat dari return saham. Dari hasil pengujian statistik diperoleh hasil bahwa konservatisme akuntansi dalam hal ini dilihat dari penjelasan konservatisme yaitu concracting, litigasi, perpajakan dan regulasi sebagai variabel independen memiliki pengaruh terhadap kepercayaan investor dilihat dari return saham sebesar $R$ square yaitu sebesar $0.4 \%$ untuk return saham. Hal ini berarti bahwa penjelasan konservatisme akuntansi yaitu concracting, litigasi, pajak dan regulasi mempunyai pengaruh sebesar $0.4 \%$ terhadap return saham. Dari hasil prosentase yang kecil tersebut memberikan indikasi bahwa ada faktor-faktor lain yang mempengaruhi return saham yang belum dimasukkan dalam penelitian ini.

\section{KESIMPULAN}

Berdasarkan hasil analisis dan pembahasan yang telah diuraikan pada bab-bab sebelumnya dan pengujian yang telah dilakukan maka dapat diambil kesimpulan sebagai berikut ini :

a. Hasil penelitian menunjukkan bahwa concracting mempunyai pengaruh yang tidak signifikan terhadap retun saham yang dibuktikan dari hasil analisis regresi berganda. Dari hasil tersebut menunjukkan bahwa concracting tidak berpengaruh terhadap return saham.

b. Hasil penelitian untuk litigasi mempengaruh yang tidak signifikan untuk return saham hal ini dapat dilihat dari hasil analisis regresi berganda. Hal ini dapat disimpulkan bahwa untuk penjelasan konservatisme dalam hal ini litigasi tidak berpengaruh dalam menentukan return saham. Investor tidak melihat faktor ini untuk mengambil keputusan yang berarti ada faktor lain yang mempengaruhi hal ini.

c. Hasil penelitian perpajakan dari hasil analisis regresi berganda menunjukan bahwa perpajakan berpengaruh signifikan return saham. Dari hasil analisis regresi 
ini dapat disimpulkan bahwa perpajakan merupakan faktor yang dijadikan pertimbangan investor untuk berinvestasi karena pajak akan mengurangi keuntungan atau laba perusahaan.

d. Sedangkan untuk hasil penelitian regulasi dari hasil analisis regresi berganda menunjukan bahwa regulasi tidak berpengaruh signifikan terhadap return saham. Dari hasil analisis regresi dapat disimpulkan bahwa regulasi tidak mempengaruhi investor untuk mengambil keputusan dalam hal ini dalam melihat return saham.

\section{DAFTAR REFERENSI}

Ahmad, J. 2007. Pengaruh risiko litigasi dan type strategi terhadap hubungan antara konflik kepentingan dan konservatisme akuntansi. SNA $X$.

Ahmed, A. S., Billings, B. K., Morton, R. M., \& Stanford-Harris, M. 2002. The role of accounting conservatism in mitigating bondholder-shareholder conflict over dividend policy and in reducing debt costs. The Accounting Review, 77(4), 867890.

Balachandran, S., \& Mohanram, P. 2011. Is the decline in the value relevance of accounting driven by increased conservatism? Review of Accounting Studies, 16(2), 272-301.

Ball, R., Kothari, S. P., \& Robin, A. 1999. The effect of international institusional factor on properties of accounting earnings. Journal of Accounting and Economics, 29, 1-52.

Ball, R., Robin, A., \& Sadka, G. 2008. Is financial reporting shaped by equity markets or by debt markets?An international study of timeliness and conservatism. Review of Accounting Studies, 13(2-3), 168-205.

Basu, S. 1997. The conservatisme principle and the asymmetric timeliness of earnings. Journal of Accounting and Economics, 24 (1), 3-37.

Beatty, A., Weber, J., \& Yu, J. J. 2008. Conservatism and debt. Journal of Accounting and Economics, 45(2-3), 154-174.

Beaver, W. H. 2002. Perspectives on recent capital market research The Accounting Review, 77(2), 453-474.

Dewi, A. 2003. Pengaruh konservatisme laporan keuangan terhadap earnings response coefficient. SNA VII, 517-525.

Published by University of Airlangga.

This is an open access article under the CC BY SA license (https://creativecommons.org/licenses/by-sa/4.0/) 
Garcia Lara, J. M., Garcia Osma, B., \& Penalva, F. 2011. Conditional conservatism and cost capital. Review of Accounting Studies, 16(2), 247-271.

Hendriksen. 1982. Accounting Theory. In R. D. Irwin (Ed.), (5th ed.).

Hothausen, R. W., \& Watts, R. L. 2001. The relevance of the value-relevance literatur for financial accounting and standard setting. Journal of Accounting and Economics, 31(1-3), 3-75.

Juanda, A. 2007. Pengaruh risiko litigasi dan type strategi terhadap hubungan antara konflik kepentingan dan konservatisme akuntansi. SNA $X$.

Kiryanto, \& Supriyanto. 2006. Pengaruh moderasi size terhadap hubungan laba konservatisme dengan neraca konservatisme. SNA IX.

Lafond, \& Watts, R. L. 2008. The informasi role of conservatism The Accounting Review, 83(2), 447-478.

Leone, A. J., Wu, J. S., \& Zimmerman, J. L. 2006. Asymmetric sensitivity of CEO cash compensation to stock return. Journal of Accounting and Economics, 42(1-2), 167-192.

Lev, B., \& Sougiannis, T. 1996. The capitalization, amortization, and value-relevance of R\&D. Journal of Accounting and Economics, 21(1), 107-138.

Lo, E. W. 2005. Pengaruh tingkat kesulitan keuangan perusahaan terhadap konservatisme akuntansi. SNA VII.

Ohlson, J. 1995. Earnings, book values, and dividens in equity valution: An empirical perspective. Contemporary Accounting Research, 18(1), 107-120.

Penman, S. H., \& Zhang, Z.-J. 2002. Accounting conservatism, the quality of earnings, and stock return. The Accounting Review, 77(2), 237-264.

Qiang, A. 2007. The effects of concracting, litigation, regulation, and tax costs on conditional and unconditional conservatism; Cross sectional evidence at the firm level. The Accounting Review, 82(3), 759-796.

Setyaningsih, H. 2008. Pengaruh tingkat kesulitan keuangan perusahaan terhadap konservatisme akuntansi. Jurnal Akuntansi \& Investasi, 62-74.

Watts, R. L. 2003a. Conservatism part I: explanation and implications. Accounting Horizons, 17(4), 287-301. 
Watts, R. L. 2003b. Conservatisme in accounting part II : evidence and research opportunities. Accounting Horizons, 17.

Watts, R. L., \& Zimmerman, J. L. 1990. Possitive Accounting Theory:A ten year perspective. The Accounting Review, 65(1), 131-156. 